\title{
Snake bite and therapeutic measures: Indian scenario
}

S. Meenatchisundaram ${ }^{1}$ and A. Michael ${ }^{2}$

\section{${ }^{1}$ Dept. of Microbiol., Nehru Arts \& Science College; ' 2 Dept. of Microbiol., PSG College of Arts \& Science, Coimbatore, India} drmscbe@gmail.com

Abstract: The Indian subcontinent, being tropical, harbors a variety of snakes. Every year $\sim 15,000$ people reportedly die due to snakebites in India. Until now, horse polyvalent antivenom is the only specific treatment for snake venom poisoning. This paper describes the occurrence of snake bite in India and their therapeutic measures in the case of snake bite envenomation.

Introduction

Snake bite remains a public health problem in many countries even though it is difficult to be precise about the actual number of cases. It is estimated that the true incidence of snake envenomation could exceed 5 million per year (Chippaux, 1998) In Asia alone, it has been estimated that a million snakebites occur each year, of which approximately $50 \%$ are envenomed, resulting in $1,00,000$ annual deaths (Sanjib et al., 2004). Although the environment, habitat and human activities determine the number of incidences due to various species, Echis carinatus claims the majority of bites in most parts of the subcontinent.

Indian subcontinent, being tropical, harbors a variety of venomous and non-venomous snakes. The major families of snakes in India are Elapidae, Viperidae and Hydrophidae (Bawaskar, 2004). The four major venomous biting species are Cobra (Naja naja), Krait (Bungarus caeruleus), Russell's viper (Vipera russelli), and Saw-scaled viper (Echis carinatus). The former two belong to the Elapidae and the latter two belong to the Viperidae family (Table 1, Fig. 1). Every year approximately 15,000 people reportedly die due to snakebites in India.

Toxicity and clinical features of bites

Snake venoms are not single toxins but a cocktail of many components like enzymes, polynucleotide toxins, non-toxic proteins, carbohydrates, metals, lipids, free aminoacids, nucleotides and biogenic amines. These combinations confer a formidable array of toxic properties on the venom, the peptides and polypeptides being responsible for a variety of toxic properties (Bawaskar, 2004). Snake venoms contain species-specific proteins with widely varying toxicological features. The Cobra venom consists of three types of proteins namely cardiotoxin, neurotoxin, and Phospholipase $A_{2}\left(P L A_{2}\right)$. The clinical manifestations of snakebite are dependent on two factors, the intrinsic toxicity and amount of venom injected. There are many signs and symptoms following envenomation by snakes, but the major ones with clinical significance can be divided into a few broad categories (a) flaccid paralysis (b) systemic myolysis (c) coagulopathy and hemorrhage (d) renal damage and failure (e) cardiotoxicity and (f) local tissue injury at the site of bite. The symptoms suggest that snake venoms affect various systems, particularly the central nervous system (CNS), cardiovascular system and muscular system (Koh et al., 2006).

Toxins belonging to cardiotoxin and neurotoxin groups are small molecular weight proteins, cross-linked by four disulfide bridges at homologous positions. In contrast to Cobra neurotoxins, which interact with the post-synaptic acetylcholine receptor, the cardiotoxins show no defined cellular targets and have very diverse pharmacological effects, including lethal toxicity, hemolysis, muscle contracture, and activation of tissue Phospholipase C. Severe inflammation and necrosis in the affected tissue area may be due to the cardiotoxins and/or $\mathrm{PLA}_{2}$ or their synergistic effect. Cobra can deliver $60 \mathrm{mg}$ of venom in a single bite, which is five times its fatal dose. Common Krait (Bungarus caeruleus) is responsible for nocturnal human bites and large mortality rate. Its bite may not be painful and the local symptoms are barely discernible, but systemic symptoms and abdominal pain are the distinctive features of a Krait envenomation, along with hypokalemia. The neurotoxins in the Krait venom are prominently pre-synaptic and prevent release of acetylcholine at the neuromuscular junctions. Krait venom has a fatal dose of $6 \mathrm{mg}$ with an average deliverable dose of $20 \mathrm{mg}$.

Cobra and Krait are neurotoxic. Soon after the bite, the patient complains of a sinking feeling, drowsiness, blurring of vision, diplopia, dysphagia and dyspnoea. There will be paralysis of palate, tongue, pharynx and respiratory muscles. There will be a flaccid paralysis of the limbs, associated with hypotonia and a diminution in the tendon reflexes. Coma and death can happen due to respiratory failure or shock in 6-48 hrs. The Russell's viper venom causes local and hemotoxic manifestations with distinctive blister formation on the affected limb. It is used as a proteolytic agent alone or synergistically with others. Hematuria, renal failure, hyper edema, hemorrhage and anemia are other typical features in Russell's viper envenomation. This snake has a fatal dose of $15 \mathrm{mg}$ and the average venom yield per bite is $63 \mathrm{mg}$. Saw-scaled viper constitutes about $80 \%$ of the total venomous bites in some geographical areas. Untreated Echis carinatus envenomation may involve multiple organs and the patient may suffer from hematuria, melena, renal failure, hemorrhage, anemia and hypotension. This snake has a fatal dose of $6.65 \mathrm{mg}$ and an average bite may yield about $40 \mathrm{mg}$ of venom (Kumar et al., 2006). Russell's viper and Saw scaled viper are histotoxic and haemorrhagic venoms. Within 3-4 hours of bite various symptoms will occur. Haemorrhagic manifestations, which appear as extensive bruises, bleeding from the bitten parts, bleeding from gums, epistaxis, blotchy purpura haemorrhagica, haématemesis and malena can oocur. Bleeding can lead to
Popular article

COIndian Society for Education and Environment (iSee)
"Snake bite \& treatment" http://www.indjst.org
Meenatchisundaram \& Michael Indian J.Sci.Technol. 
shock. Cardiac manifestations occur as tachycardia, scaled viper) occurs in both India and Pakistan, where it myocarditis and cardiac failure.

is responsible for a large number of snake bite case,

\begin{tabular}{|c|c|c|c|c|c|c|}
\hline Name & $\begin{array}{c}\text { Distinctive } \\
\text { Features }\end{array}$ & $\begin{array}{l}\text { Average } \\
\text { Length }\end{array}$ & Distribution & Habitat & Common Prey & $\begin{array}{l}\text { Type of } \\
\text { toxicity }\end{array}$ \\
\hline $\begin{array}{l}\text { Indian cobra } \\
\text { (Naja Naja) }\end{array}$ & $\begin{array}{l}\text { Medium size to } \\
\text { large, smooth, } \\
\text { shiny scales }\end{array}$ & $\begin{array}{l}1 \mathrm{~m}, \\
\text { At birth } 25 \mathrm{~cm} \\
\text { male } 2 \mathrm{~m}\end{array}$ & $\begin{array}{l}\text { Throughout India } \\
\text { sea level upto } \\
4000 \mathrm{~m}\end{array}$ & $\begin{array}{l}\text { Common in } \\
\text { Rice growing } \\
\text { Areas }\end{array}$ & $\begin{array}{l}\text { Small snakes, } \\
\text { Insect, } \\
\text { Lizards. }\end{array}$ & Neurotoxic \\
\hline $\begin{array}{l}\text { Common krait } \\
\text { (Bungarus } \\
\text { caeruleus) }\end{array}$ & $\begin{array}{l}\text { Medium sized, } \\
\text { Smooth, glossy } \\
\text { scales }\end{array}$ & $\begin{array}{l}1 \mathrm{~m}, \\
\text { At birth } 25 \mathrm{~cm} \\
\text { male } 1.75 \mathrm{~m}\end{array}$ & $\begin{array}{l}\text { Most of India } \\
\text { Sea level up to } \\
1700 \mathrm{~m}\end{array}$ & $\begin{array}{l}\text { Sandy soil, } \\
\text { Termite mounds } \\
\text { Piles of brick }\end{array}$ & $\begin{array}{l}\text { Mainly snakes } \\
\text { Lizards \& } \\
\text { rodents }\end{array}$ & Neurotoxic \\
\hline $\begin{array}{l}\text { Saw-scaled } \\
\text { viper (Echis } \\
\text { Carinnatus) }\end{array}$ & $\begin{array}{l}\text { Small, strongly } \\
\text { keeled scales, } \\
\text { dull colour }\end{array}$ & $\begin{array}{l}\text { South India: } 30 \mathrm{~cm} ; \\
\text { North India: } 50 \mathrm{~cm} . \\
\text { At birth: } 8 \mathrm{~cm}, \text { Max. } 80 \mathrm{~cm}\end{array}$ & $\begin{array}{l}\text { Throughout India, } \\
\text { mostly plains, Up to } \\
2000 \mathrm{~m} \text { in hills }\end{array}$ & $\begin{array}{l}\text { Not found in the } \\
\text { heavily Forested } \\
\text { area \& hills }\end{array}$ & $\begin{array}{l}\text { Mice, Lizard, } \\
\text { Frogs. }\end{array}$ & Hemorrhagic \\
\hline
\end{tabular}

Description

Cobra - Cobras are medium size to large, smooth shiny scales, wide head and neck, wide black band on underside of neck, Distinctive hood mark on top of the neck (Fig.1).

Krait - Kraits are medium sized with an average length of $1 \mathrm{~m}$ and smooth, glossy bluish black snakes with the rounded head slightly distinct from the neck. There are normally about 40 thin white cross bands.

Russells viper-Russells viper are medium sized to large, strongly keeled scales, distinctive bright chain pattern, large triangular head.

Saw scaled viper - Saw scaled vipers are small, strongly keeled scales, head wider than neck, dull colour, cross mark on top of the head.

\section{Epidemiology of snake bite}

Snakebites are not systematically reported in most countries. Moreover, very few countries possess a reliable epidemiological reporting system capable of providing precise data on snake bites (Chippaux, 1998). Most of the available data are based on hospital statistics which constitute a very small percentage of cases of snake bite because these cases are still being treated mostly by witch craft and traditional methods rather than in the hospitals. In Asia alone, it has been estimated that four million snake bites occur each year of which $50 \%$ are envenomed resulting in one lakh annual death (Sanjib et al., 2004). In India, $\sim 15,000$ people are affected every year by snake envenomation (Shashidharamurthy \& Kemparaju, 2007). In Sri Lanka, the overall annual mortality from a single venomous species ranges from 5.6 per 100,000 to as high as 18 per $1,00,000$ in some areas. About $97 \%$ of snake bite deaths in Sri Lanka were due to common Krait and Russell's viper bites (Kularatne, 2002). Myanmar seems to have the highest mortality rate in Asia and $70 \%$ snakebites are by Russell's viper. However, this may only reflect a better reporting system prevalent in this country, where the reporting of snake bite deaths has been obligatory for many years. In India, data are fragmentary because less than $40 \%$ of snake bite patients attend public hospitals. Echis carinatus (Saw- reaching $95 \%$ of envenomations in the state of Jammu. Vipera russelli also are frequently encountered in India and throughout South-East Asia. In Maharastra, highest incidence reported 70 bites per 100,000 population and mortality of 2.4 per 100,000 per year (Chippaux, 1998). Snake-bite cases were observed in almost all age groups (except >81yr), the majority being in males aged 21-50 yr, while the male to female ratio was $3: 1$. In the previous studies reported from Ambajogai (Maharashtra) and Karnataka, the male to female ratio was found to be 3.2:1 and $2: 1$, respectively. Studies from other countries also indicate male victim preponderance; male: Female ratio was reported as 1.9:1 in Thailand and 1.3:1 in Pakistan. The predominance of male victims suggests a special risk of outdoor activity. The commonly affected age groups were observed to be 10-40 yr in Nepal, 15-44 yr in Pakistan and 6-40 yr in Zimbabwe (Ganneru Brunda \& Sashidhar, 2007).

Snake bite is primarily a problem of the poorer rural populations in these regions and affects mainly those involved in subsistence farming activities. Poor access to health services in these settings and, in some instances, a scarcity of antivenom, often leads to poor outcomes and considerable morbidity and mortality. Many victims fail to reach hospital in time or seek medical care after a considerable delay because they first seek treatment from traditional healers. Some even die before reaching hospital. Hospital statistics on snakebites therefore underestimate the true burden. In addition to mortality, some snakebite victims survive with permanent physical sequelae due to local tissue necrosis and, sometimes psychological sequelae. Because most victims are young, the economic impact of snakebite can be considerable. In the rural tropics, victims are often bitten in an agricultural field or jungle, and in many instances the biting species is not identified. In such situations, treatment with polyspecific rather than monospecific antivenoms may be more appropriate. The need for many different antivenoms means that production is not always economically viable and in some parts of the world, particularly Africa, there is a crisis regarding production,
Popular article

Clndian Society for Education and Environment (iSee)
"Snake bite \& treatment" http://www.indjst.org
Meenatchisundaram \& Michael Indian J.Sci.Technol. 
distribution and accessibility of antivenoms. In addition, the need to restrict the cost of these products when manufactured on a small scale means that relatively limited processing leads to high adverse reaction rates with some products, including life threatening anaphylaxis. Another problem is that currently available antivenoms are not effective against the local necrotic effects of snake venom which can lead to long-term disability and disfigurement. In addition to antivenom therapy, management of snakebite also includes supportive therapy, such as ventilation for respiratory paralysis, which is often lifesaving for victims bitten by species which cause severe neurotoxicity.

The age and sex incidence of snakebite

The age and sex incidence of snakebite victims throw light on the vulnerable section of the population. While snakebite is observed in all age groups, the large majority $(90 \%)$ are males (courtesy from www. webindia 123.com)

A) Cobra (Naja naja), B) Krait (Bungarus caeruleus), C) Russell's viper (Vipera russelli), D) Saw-scaled viper (Echis carinatus)

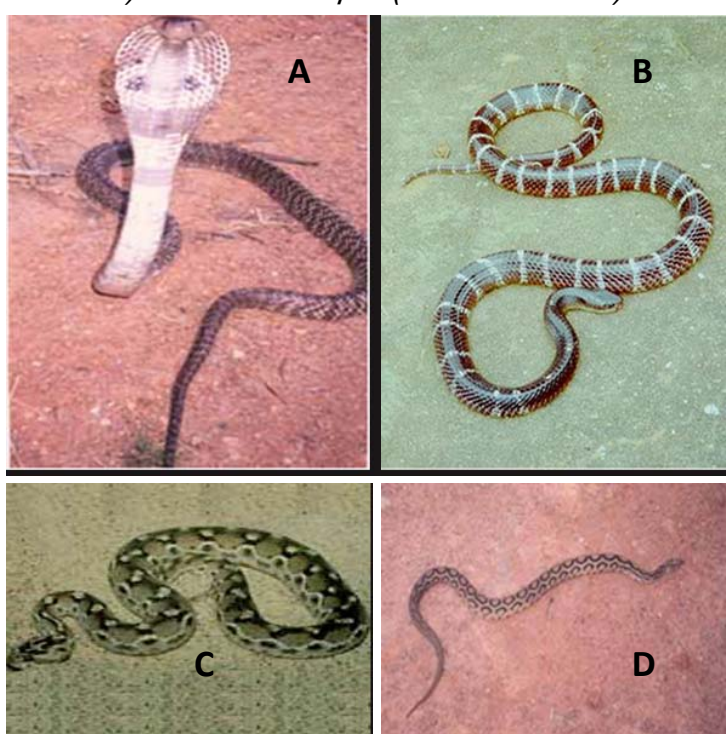

Fig. 1 Common poisonous snakes found in India

undeveloped land, are the worst affected. These include farmers, herders, hunters and workers on development sites. Morbidity and mortality resulting from snakebite envenomation also depends on the species of snake involved, since the estimated 'fatal dose' of venom varies with species. In the Indian setting, almost two-thirds of bites are attributed to Saw-scaled viper (as high as $95 \%$ in some areas like Jammu), about one fourth to Russell's viper and smaller proportions to Cobra and Kraits. In Sri Lanka, Vipera russelli accounts for $40 \%$ of bites and Naja naja for another $35 \%$. Among the various species, the average yield per bite in terms of dry weight of lyophilized venom is $60 \mathrm{mg}$ for Cobras, 63mg for Russell's viper, $20 \mathrm{mg}$ for Krait and 13mg for Sawscaled viper. The respective 'fatal doses' are much smaller viz $12 \mathrm{mg}$, $15 \mathrm{mg}, 6 \mathrm{mg}$ and $8 \mathrm{mg}$. However, clinical features and outcomes are not as simple to predict because every bite does not result in complete envenomation.

Epidemics of snake bite following floods owing to human and snake populations getting concentrated together have been noted in Pakistan, India and Bangladesh (Reid, 1982).

Antivenom therapy

Since the discovery of antivenin by Calmette in 1894, the method for preparation has little modified. The basic principle is to immunize an animal with venom for production of specific antibodies that will be able to neutralize this venom. There is a need for antivenin producers to modernize the techniques.

Antivenoms constitute the mainstay in the treatment of snake bite envenomations. Antivenoms are currently produced in many laboratories around the world with very different immunization protocols and methodologies for immunoglobulin purification. Snake venom was injected in small amounts into mammals such as horses, sheep or rabbits. These animals have an immune response whereby antibodies against venom are generated naturally. The antivenom is then harvested from the blood of the animal, purified and stored. In India polyvalent antisnake venom effective against venoms of Cobras, Krait, Russell's viper and Saw-scaled viper is available. Each $\mathrm{ml}$ of polyvalant antisnake venom can neutralize $0.6 \mathrm{mg}$ of Cobra, $0.6 \mathrm{mg}$ of Russell's viper, $0.45 \mathrm{mg}$ of Krait and $0.45 \mathrm{mg}$ of Saw-scaled viper venom (Bawaskar, 2004). Antivenoms may be species specific (monovalent) or effective against several species (polyvalent). Monovalent antivenom is ideal, but the cost and nonlifestyla 
availability, besides the difficulty of identifying the snakes makes its use difficult (Kumar et al., 2006).

Administration

Two major problems are reported that concern the administration route and the quantity of antivenin delivery. Most authors admit that the intravenous route (IV) is the best. Practitioners prefer to mix antivenin with fluid (e.g., saline, dextrose, or glucose solution) to the final dilution of $5-10 \%$ antivenin; $500 \mathrm{ml}$ of the mixture should be delivered within the first $30 \mathrm{~min}$. This method is relevant because risk of adverse reactions is reduced and symptomatic or systemic drugs can be added to the mixture. Few physicians slowly inject pure antivenin into the vein. This method should be possible in an extreme emergency, and has to be considered as a type of lastchance treatment. The intravenous route is preferable because it is more efficient (about $75 \%$ of injected dose is available) and the effect is quick (Chippaux \& Goyffon, 1992). Chippaux (1982) stressed that local subcutaneous injection is painful and poorly efficient. Diffusion of venom in the body is very fast, and even if antigens are fixed all around the bite, it is preferable to washing them away. Antivenin injected in situ leads to antigen precipitation and some of these could be still toxic. This could enhance the risk of local damage caused by proteolytic enzymes. The quantity of antivenin delivered depends on the clinical features and delay time after the bite. It also depends on the known or documented efficacy of available antivenin. For large venomous species, at least four vials (e.g., 40 $\mathrm{ml}$ ) are recommended by most specialists (Russell, 1980). This recommendation is for highly venomous species and can be doubled for those that inject a large amount of venom. The principle of serotherapy is a target strategy. It
Table 2 - Age distribution (Narvencar, 2006)

\begin{tabular}{|c|c|c|c|}
\hline $\begin{array}{c}\text { Age } \\
\text { group }\end{array}$ & $\begin{array}{c}\text { Total } \\
\text { cases }\end{array}$ & $\begin{array}{c}\text { Compli- } \\
\text { cated }\end{array}$ & $\begin{array}{c}\text { Uncomp- } \\
\text { licated }\end{array}$ \\
\hline $0-10$ & 00 & 00 & 00 \\
\hline $11-20$ & 11 & 02 & 09 \\
\hline $21-30$ & 11 & 05 & 06 \\
\hline $31-40$ & 11 & 02 & 09 \\
\hline $41-50$ & 09 & 05 & 04 \\
\hline $51-60$ & 04 & 02 & 02 \\
\hline$>60$ & 04 & 04 & 00 \\
\hline Total & 50 & 20 & 30 \\
\hline
\end{tabular}

Products of animal serum can produce adverse side effects such as anaphylactic reactions and serum sickness (Gold et al., 2002). Scientists at Vittal Mallaya Scientific Research Foundation generated antivenom specific antibodies in white leghorn chicken and their egg yolks. They recently reported that the purity, efficacy and ease of manufacture of avian antivenoms and their inability to react with mammalian complement make them an attractive alternative to equine antivenoms. It is also specified that over $10-15 \mathrm{mg}$ of venom specific antibodies can be obtained from an immunized chicken's egg yolk. Almeida et al. (1998) reported that adult white leghorn hens hyperimmunized with Brazilian snake venoms produced antibodies capable of recognizing, combining with and neutralizing the toxic and lethal components of the venoms. Paul et al. (2007) worked on the generation of anti- E.carinatus antivenom in chicken egg yolk and its efficacy in neutralizing the lethal effects of E.carinatus venom and reported this system as a more convenient alternative to current conventional production of equine anti-snake venom. Meenatchisundaram et al. (2008a,b) have worked on pharmacological effects of Russell's viper and Saw-scaled viper venom and its neutralization by chicken egg yolk antibodies and stated that the antibodies raised in chicken could effectively neutralize the pharmacological effects induced by venoms and chickens therefore present an alternative and cheaper source of specific antibody generation. They also worked on neutralization of the pharmacological effects of Cobra and Krait venom by chicken egg yolk antibodies and indicated that the antivenom generated in chicken could be used for therapeutic purposes in case of snakebite envenomation. Recently Almeida et al (2008) developed a process to produce polyvalent IgY antibodies from chicken against African snakes which showed high antivenom activity and efficacy in neutralizing the venom lethality.

Standardization, quality control and safety of antivenom

Quality control of immunoglobulin products needs to assess their efficacy and safety. Efficacy testing should address batch-to-batch consistency and stability. Safety testing includes procedures designed to ensure freedom from infectious agents and also safety in respect to causing adverse reactions in recipients. WHO has produced recommendations for desirable characteristics $\begin{aligned} & \text { Chicken antibodies as an alternative source to horse of human immunoglobulin preparations as well as for viral } \\ & \text { antibodies }\end{aligned}$ Table 3. Sex distribution (Narvencar, 2006) inactivation and removal. The antibodies

Until now, anti snake venom for neutralizing snake bite venom has been made by injecting horses with small

\begin{tabular}{|c|c|c|c|}
\hline Victims & Total cases & Complicated & Uncomplicated \\
\hline Males & 45 & 17 & 28 \\
\hline Females & 05 & 03 & 02 \\
\hline Total & 50 & 20 & 30 \\
\hline
\end{tabular}
antivenom potency assays used in various countries indicated that most accepted the standard murine lethality quantities of venom to produce an immune reaction. assay $\left(L D_{50}\right.$ of venom and $E D_{50}$ of antivenom) as the Antibodies are then harvested from the animal's blood. yardstick for assessing antivenom preparations. About 5 
to 6 mice of a particular weight per dose, challenged intravenously or occasionally intraperitoneally with venom preincubated with different doses of antivenom were used in this assay. There was considerable variation in the details of how the test was carried out, with different volumes injected, different numbers of $\mathrm{LD}_{50}$ and different routes used for injecting venom/antivenom mixtures, weight range and strain of mice used. Local venom reference preparations and standard antivenom preparations are essential to standardize these assays and to allow batch to batch comparisons as well as comparisons between different laboratories. Ideally antivenom activities should be expressed in toxin neutralizing units based on national or regional standards (Theakston et al., 2003). Quality control should also include measurement of the ability of the antivenom to neutralize the lethal activities and other clinically relevant pharmacological activities of the corresponding venoms. Conclusion

Snakebite is a significant health hazard that leads to high mortality rate especially in India. Every year $\sim 15,000$ people reportedly die due to snakebites in India. Antisnake venom remains the specific antidote for snake venom poisoning. This antisnake venom is usually derived from horse sera. In severe envenomation, large amounts of antivenin must be injected and adverse reaction risks are increased. Preservation of antivenin in tropical countries remains problematic. The cost of antivenin limits the supply where such a therapy is strongly useful. One solution could be to improve antivenin manufacturing to better concentrate the specific antibody activity and remove any unsuitable proteins. It would be necessary to identify the toxic components in venoms and to discard venom antigens that are not involved in the envenomation. Many scientists worked on chicken antibodies for production of antivenom, as compared to traditional method of obtaining antibodies from mammalian serum. The purity, efficacy and ease of manufacture of avian antivenoms and their inability to react with mammalian complement make them an attractive alternative to equine antivenoms. Avian egg yolk antibodies will play a major role in treatment of snakebite envenomations (immunotherapy) in future.

\section{References}

1. Almeida CMC, Kanashiro MM, Rangel Filho FB, Mata MFR, Kipnis TL and Diasda Silva W (1998) Development of snake antivenom antibodies in chickens and their purification from yolk. Veterinary Record. 143, 579- 584.

2. Almeida CMC, Da Silva CL, Couto HP, Escocard Rde C, DA ROCHA DG, Sentinelli Lde P, Kipnis TL, da Silva WD. (2008) Development of process to produce polyvalent IgY antibodies anti-African snake venom. Toxicon. 52(2):293301.

3. Gold BS, Richard C. Dart and Robert A. Barish (2002) Bites of venomous snakes. N. Engl. J. Med. 347 (5), 347- 356.

4. Bawaskar HS (2004) Snake venoms and antivenoms: critical supply issues. JAPI. 52, 11-13.
5. Chippaux JP, Boche J and Courtois B (1982) Electrophoretic patterns of the venom from a litter of Bitis gabonica snakes. Toxicon. 20, 521-523

6. Chippaux JP (1998) Snake-bites: appraisal of the global situation. Bull WHO. 76, 515- 524.

7. Ganneru Brunda and Sashidhar RB (2007) Epidemiological profile of snake-bite cases from Andhra Pradesh using immunoanalytical approach. Indian J. Med. Res. 125, 661668.

8. Chippaux JP and Goyffon M (1992) Production and use of snake antivenin. Handbook of Natural Toxins. Marcel Dekker, INC. pp: 537- 538.

9. Koh DCl, Armugam A and Jeyaseelan K (2006) Snake venom components and their applications in biomedicine. Cell. Mol. Life Sci. 63, 3030-3041.

10. Kularatne SAM (2002) Common krait (Bungarus caeruleus) bite in Anuradhapura, Sri Lanka: a prospective clinical study, 1996-98. Postgrad Med. J. 78, 276-280.

11. Kumar V, Maheshwari R, Verma HK (2006) Toxicity and symptomatic identification of species involved in snakebites in the Indian subcontinent. J.Venom.Anim.Toxins Incl. Trop.Dis. 12, 3-18.

12. Meenatchisundaram S, Parameswari G, Michael $A$ and Ramalingam S (2008a) Studies on pharmacological effects of Russell's viper and Saw-scaled viper venom and its neutralization by chicken egg yolk antibodies. Int/. Immunopharm. 8, 1067- 1073.

13. Meenatchisundaram S, Parameswari G, Michael A and Ramalingam S (2008b) Neutralization of the pharmacological effects of Cobra and Krait venom by chicken egg yolk antibodies. Toxicon. 52, 221- 227.

14. Narvencar K (2006) Correlation between timing of ASV administration and complications in snake bites. JAPI. 54, 717- 719 .

15. Paul K, Manjula J, Deepa EP, Selvanayagam ZE, Ganesh KA and Subba Rao PV (2007) Anti-Echis carinatus venom antibodies from chicken egg yolk: isolation, purification and neutralization efficacy. Toxicon. 50 (7), 893-900.

16. Reid HA (1982) Animal poisons. In: Manson bahr PEC, Apted FIC, (Eds). Mansons Tropical diseases, $18^{\text {th }}$ ed. London. Balliere-Tindall. pp: $544-546$.

17. Russell FE (1980) Snake venom poisoning. Lippincott JB, Philadelphis.

18. Sanjib K. Sharma, Francois Chappiux, Nalhamb Arjha, Patrick A. Bovier, Louis Loutan and Shekhar Koirala (2004) Impact of snake bites and determinants of fatal outcomes in southeastern Nepal. Am.J.Trop.Med.Hyg. 71(2), 234- 238.

19. Shashidharamurthy R and Kemparaju K (2007) Regionspecific neutralization of Indian cobra (Naja naja) venom by polyclonal antibody raised against the eastern regional venom: A comparative study of the venoms from three different geographical distributions. Intl. Immunopharm. 7, 61- 69.

20. Theakston RDG and Reid HA (1979) Enzyme-linked immunosorbent assay (ELISA) in assessing antivenom potency. Toxicon. 17, 511- 515.

21. Theakston RDG, Warrell DA and Griffiths E (2003) Erratum to report of WHO workshop on the standardization and control on antivenoms. Toxicon. 41(5), 541- 557.

22. Whitaker R (1978) Common Indian snakes. A field guide. McMillan India Ltd. pp: 1-103.
Popular article

COIndian Society for Education and Environment (iSee)
"Snake bite \& treatment" http://www.indjst.org
Meenatchisundaram \& Michael Indian J.Sci.Technol. 